\title{
Original Paper \\ Trichocline minuana (Compositae, Mutisieae), a new species endemic to the Pampas in Southern Brazil and Uruguay
}

\author{
Eduardo Pasini ${ }^{1,2,3}$ \& Silvia Teresinha Sfoggia Miotto ${ }^{1}$
}

\begin{abstract}
A new species of the genus Trichocline is described. Trichocline minuana is restricted to the state of Rio Grande do Sul, Brazil and northern Uruguay, where is found in lowland pampean grasslands, generally associated to rocky and dry soils. The main characters that distinguish this species from the other sympatric and morphologically close species T. humilis and T. incana are the presence of a small scape and strongly pinnatisect leaves that have lobes with acute apex, and a large, lanceolate terminal lobe. This study provides a detailed description of the species, information about distribution, conservation status assessment and information about its ecological aspects.
\end{abstract}

Key words: Asteraceae, campanha gaúcha, lowland grasslands, Rio Grande do Sul state.

\section{Resumo}

Uma nova espécie do gênero Trichocline é descrita. Trichocline minuana é restrita ao Rio Grande do Sul, Brasil e norte do Uruguai, onde ocorre em campos pampeanos de baixa altitude, geralmente associados com afloramentos rochosos e solos secos. As principais características que diferenciam esta espécie de Trichocline humilis e T. incana, ambas espécies simpátricas e morfologicamente próximas, são a presença de um escapo curto e folhas fortemente pinatissectas com lobos de ápice agudo e um lobo terminal lanceolado. Este estudo apresenta uma descrição detalhada e informações sobre a distribuição da espécie, estado de conservação e aspectos ecológicos

Palavras-chave: Asteraceae, campanha gaúcha, campos de baixa altitude, Rio Grande do Sul.

\section{Introduction}

The genus Trichocline Cass. (Asteraceae, Compositae) belongs to the tribe Mutisieae, and is nested in the Gerbera-Complex in a South American endemic clade which also contains the genera Lulia Zardini and Brachyclados D.Don. There are approximately 23 described species of this genus and they are distributed into two main centers of diversity (Zardini 1975); one is along the Andes from southern Peru to southern Patagonia and the other is in the Southern Brazilian Plateau and Pampean Biogeographic Province (Cabrera \& Willink 1973) in Uruguay, Northeasteran Argentina and Rio Grande do Sul state in Brazil.
Some of the species frequently present a wide range distribution, along the highland grasslands in Brazil and in the Andes in Argentina, but others are rare and restricted (Zardini 1975). Ten species are distributed along the Southern Brazilian Plateau, from the highland grasslands with Araucaria Forests to the lowland grasslands and coastal Plain in Southern Brazil and Uruguay. All the species are perennial herbs, and the habit can vary from caulescent herbs with alternate leaves and axillary scapes to acaulescent herbs with rosette leaves and terminal scapes. The genus presents conspicuous monocephalous capitula with colorful bilabiate florets, where the rays have a long abaxial lobe.

\footnotetext{
${ }^{1}$ Universidade Federal do Rio Grande do Sul, Prog. Pós-graduação em Botânica, Av. Bento Gonçalves 9500, 91501-970, Porto Alegre, RS, Brazil.

${ }^{2}$ ORCID: <https://orcid.org/0000-0001-7733-9430>

${ }^{3}$ Author for correspondence: eddpasini@gmail.com
} 
One of the main morphological characters that distinguishes Trichocline from the other genera of the Gerbera-Complex are the presence of staminodes in the ray florets and a cypsela that is truncate at the apex, with long and claviform twin hairs covering the whole extension (Zardini 1975; Katinas et al. 2008).

During systematic studies of the tribe Mutiseae, led by the first author, we found a new species occurring in rocky soils along lowland grassland vegetation of the Pampa Phytogeographic Region, in Southern Brazil and Uruguay. We provide a taxonomic description, illustrations, conservation status assessment, and a distribution map.

\section{Materials and Methods}

We have conducted fieldtrips to the locations where the species was collected, and revised the following herbaria: CRI, CTES, ESA, FLOR, FURB, GH, HAS, HB, HBR, HUEFS, HUFU, HURG, ICN, LP, M, MBM, MO, MPUC, MVFA, MVJB, MVM, NY, P, PACA, SALLE, SMDB, SPF, SI and US which are cited according to Thiers (continuously updated).

The morphological nomenclature followed Beentje (2010) and the measurements were taken from dried herbarium samples. General information about the taxon's distribution, habitat and phenology was taken from herbarium sheets and observations in the field.

The conservation status assessment was based on IUCN (2016) criteria, and area of occupancy and extent of occurrence were calculated with Kew's Geospatial Conservation Assessment Tool - GeoCAT (<http://geocat.kew.org $>)$.

\section{Results \& Discussion}

Taxonomic treatment

Trichocline minuana E.Pasini, sp. nov. Type: BRAZIL. RIO GRANDE DO SUL: Quaraí, Quatepe, estrada do Passo da Guarda, RS 060, $30^{\circ} 18^{\prime} 45.8^{\prime \prime} \mathrm{S}, 56^{\circ} 04^{\prime} 27.0^{\prime \prime} \mathrm{W}$, II.2012, fl., P. P. A. Ferreira et al. 873 (Holotype: ICN!; Isotype: SI!).

Figs. 1; 2

The new species is morphologically close to T. humilis Less. and T. incana Cass., and they are sympatric. The morphological differences between the new taxon and T. humilis are the strongly pinnatisect leaves with large and lanceolate lateral and terminal lobes, often forming secondary lobes (vs. entire or pinnatisect, with small and rounded lateral and terminal lobes), lobes with acute apex (vs. rounded apex), terminal lobe large and lanceolate (vs. small, rounded not conspicuous terminal lobe) and tomentose indument in the involucral bracts and scape ( $v s$. glabrous or glabrescent). The short scape of T. minuana is also observed in T. humilis, however it is less frequent in this species. Moreover, the new taxon can be distinguished from $T$. incana by the short scapes (vs. long scapes), involucre bracts with brownish margins (vs. greenish margins) and the presence of a large lanceolate terminal lobe in the leaves (vs. short lanceolate terminal lobe).

Herbs perennial, acaulescent. Xylopodium up to $12 \times 2 \mathrm{~cm}$. Leaves rosulate, long-petiolate, petiole 0.5-6 cm long; blade discolorous, glabrous above and glabrescent to tomentose beneath, lanceolate, 4-14 $\times 0.5-4 \mathrm{~cm}$, base attenuate, margin strongly pinnatisect, entire in early stages of development, up to 4 pairs of lanceolate lobes with acute apex, terminal lobe conspicuous, lanceolate, apex acute, $2-5.5 \times 1-2 \mathrm{~cm}$. Inflorescence monocephalous, scapigerous, scape glabrescent, $1-5 \mathrm{~cm}$ long when flowering, terminal, erect, generally ebracteate, rarely with one linear bract at the base of the head. Capitula radiate, heterogamous; involucre hemispheric to campanulate, $1.2-2.5 \times 1.5-3 \mathrm{~cm}$; phyllaries 4-6-seriate, apex reflexed, imbricate, green, margin brownish, the outermost phyllaries spreading, lanceolate and spathulate to linear and spathulate, $8-25 \times 1-4 \mathrm{~mm}$, adaxial surface glabrescent to tomentose, apex acute, eventually mucronate, the median phyllaries ovate and spathulate, $10-18 \times 2.5-5 \mathrm{~mm}$, adaxial surface tomentose, apex acute, mucronate, the inner most phyllaries oblong to linear, membranaceous, $12-17 \times 3-4 \mathrm{~mm}$, glabrous to glabrescent on both surfaces, apex acuminate, brownish red at apex and margins; receptacle concave, alveolate, fimbriate. Florets dimorphic, ray florets pistillate, uniseriate, 12-18, corollas bilabiate, abaxial lip liguliform, lanceolate, $13.5-22 \times 3.5-5 \mathrm{~mm}$, 3-lobed in the apex, adaxial surface tomentose, with 4-celled trichomes, sparsely distributed, adaxial lip bisect, lobes filiform and spiral, 8-12 $\mathrm{mm}$ long; corolla yellow-orange, tube 6.5-10 mm long, with 4-celled trichomes sparsely distributed; staminodes 5, 2-4 $\mathrm{mm}$ long, apex acute to acuminate, base caudate, papillose, margin reflex near the apex when acuminate; style 14-20 mm long, bifid, exserted, style lobes dorsally papillose, $0.8-1 \mathrm{~mm}$ long; disc florets bisexual, 50-80, corollas bilabiate, abaxial lip 3-lobed, reflex to revolute, $2.5-4 \times$ ca. $1 \mathrm{~mm}$, with 4-celled trichomes sparsely distributed, adaxial 

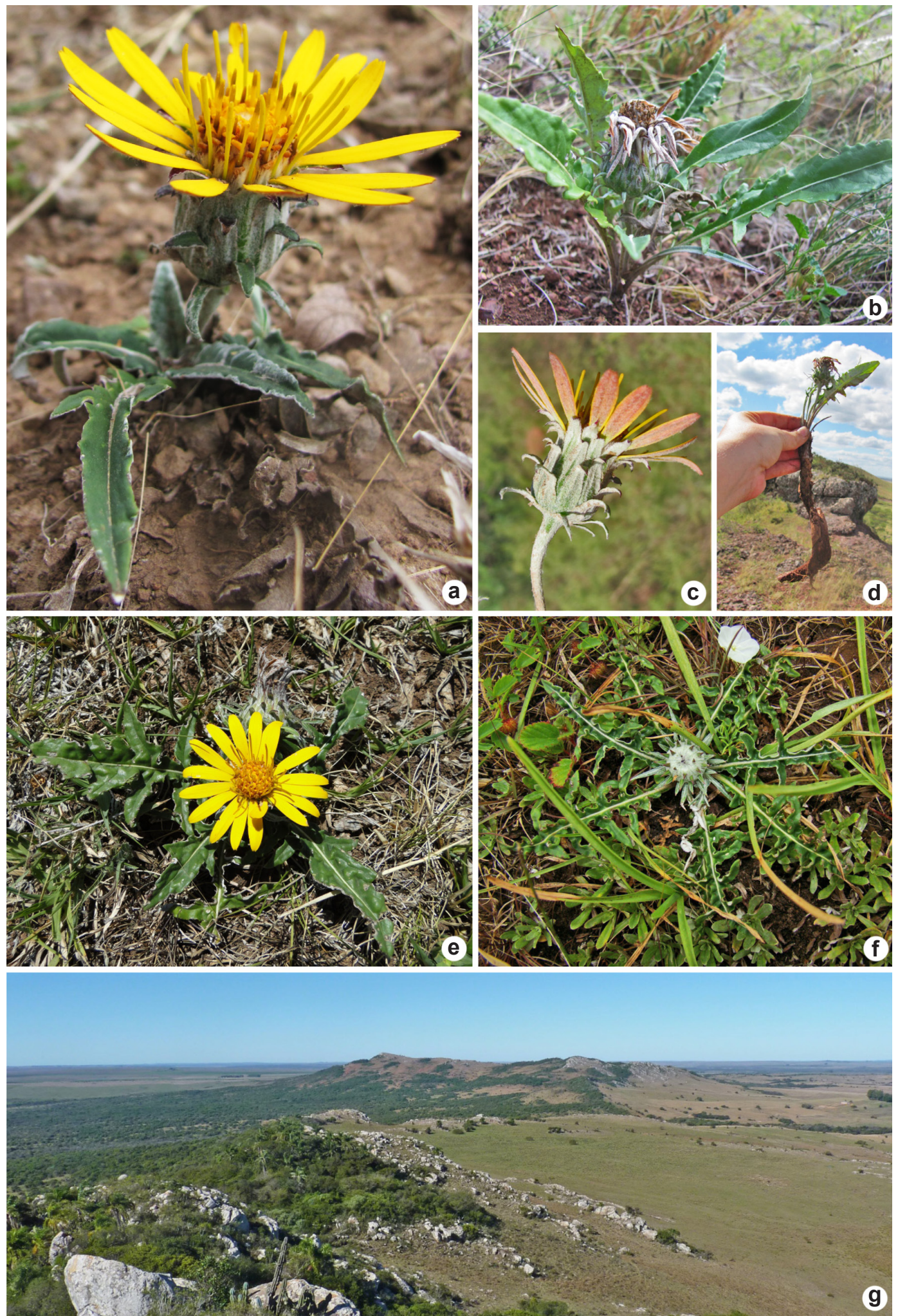

Figure 1 - a-g. Trichocline minuana - a. habit; b,e,f. habit with details of heads and pinnatisect leaves; c. involucre with imbricate phyllaries; d. detail of xylopodium; g. habitat, Municipality of Quaraí, Cerro do Jarau, Rio Grande do Sul, Brazil. Photos credits: a,b,c,d. J. Durigon; e. D. Dutra Saraiva; f. A. Schneider; g. E. Pasini. 
lip bisect, lobes lanceolate, reflex to revolute, 2.5-4 $\mathrm{mm}$ long, corolla tube 12-15 mm long; stamens 7-10 mm long, apical appendages lanceolate, apex acute, basal appendages caudate, papillose, 2-3.5 $\mathrm{mm}$ long, filaments papillose at the base, style 14-17 mm, bifid, exserted, style lobes dorsally papillose, ca. $1 \mathrm{~mm}$ long. Cypselae heteromorphic, the inner well-developed, obovate or obconical, $8 \times 6 \mathrm{~mm}$, the outer probably sterile, fusiform, both truncate at the apex, with whitish 2-seriate trichomes, inflated at the apex, densely distributed; pappus uniseriate, 14-16 mm long, whitish, with filiform bristles.
Trichocline minuana occurs in the Pampean Biogeographical Province (Cabrera \& Willink 1975), located in the southernmost Brazilian state of Rio Grande do Sul (physiographic region known as Campanha Gaúcha) and northern Uruguay (Departments of Tacuarembó, Rivera and Salto), (Fig. 3) where is endemic. Wide-open areas of grasslands are the dominant floristic physiognomy. The populations are found along herbaceous vegetation of lowland grasslands, often associated with rocky outcrops or thin and dry soils. The elevation records range from 20-200 m. According to the IUCN (2016) red list we

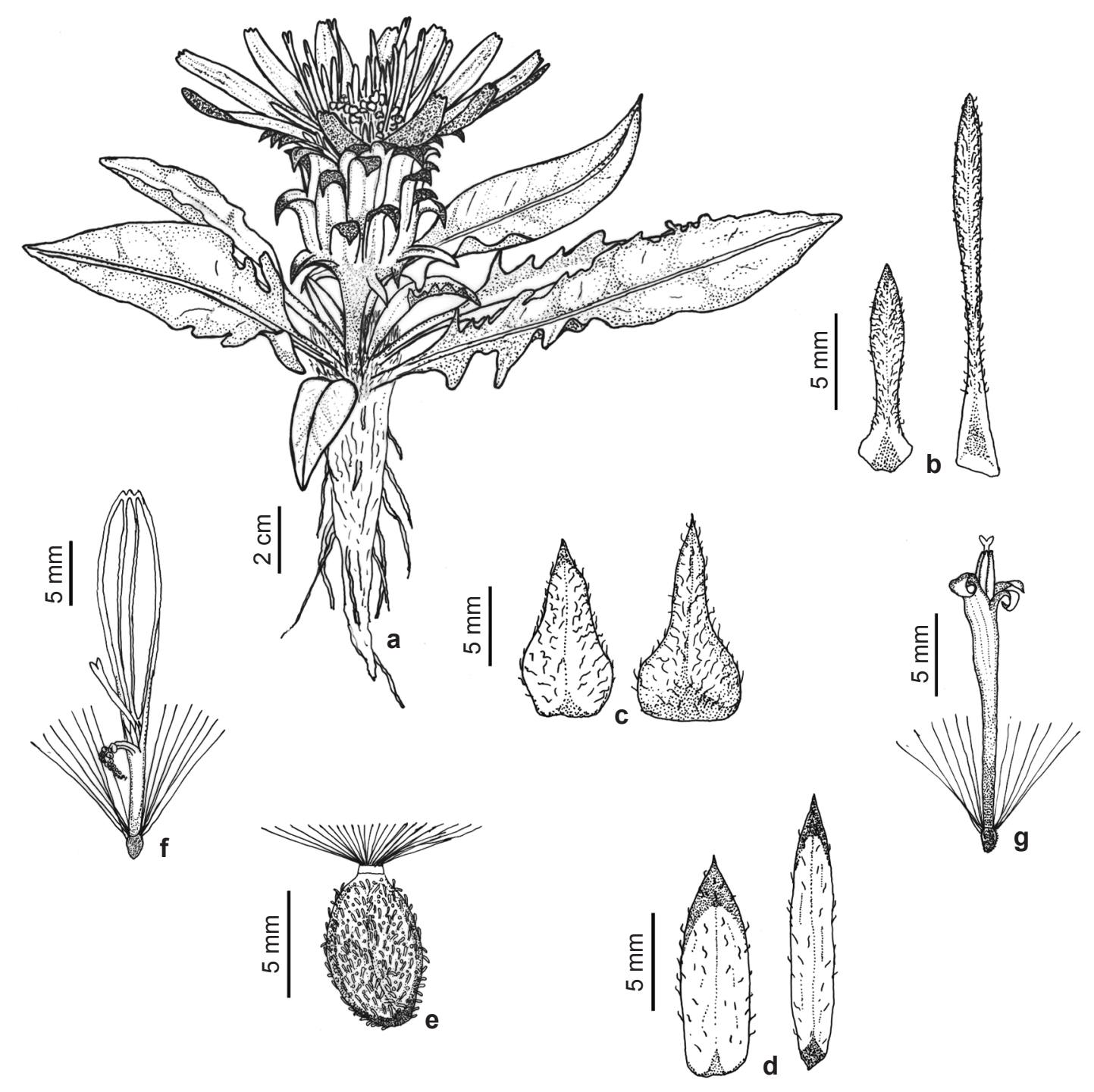

Figure 2 - a-g. Trichocline minuana - a. habit; b. outermost phyllaries; c. intermediate phyllaries; d. innermost phyllaries; e. cypsela; f. pistillate ray floret; g. bisexual disc floret. (a-g. P.P.A. Ferreira et al. 873) 


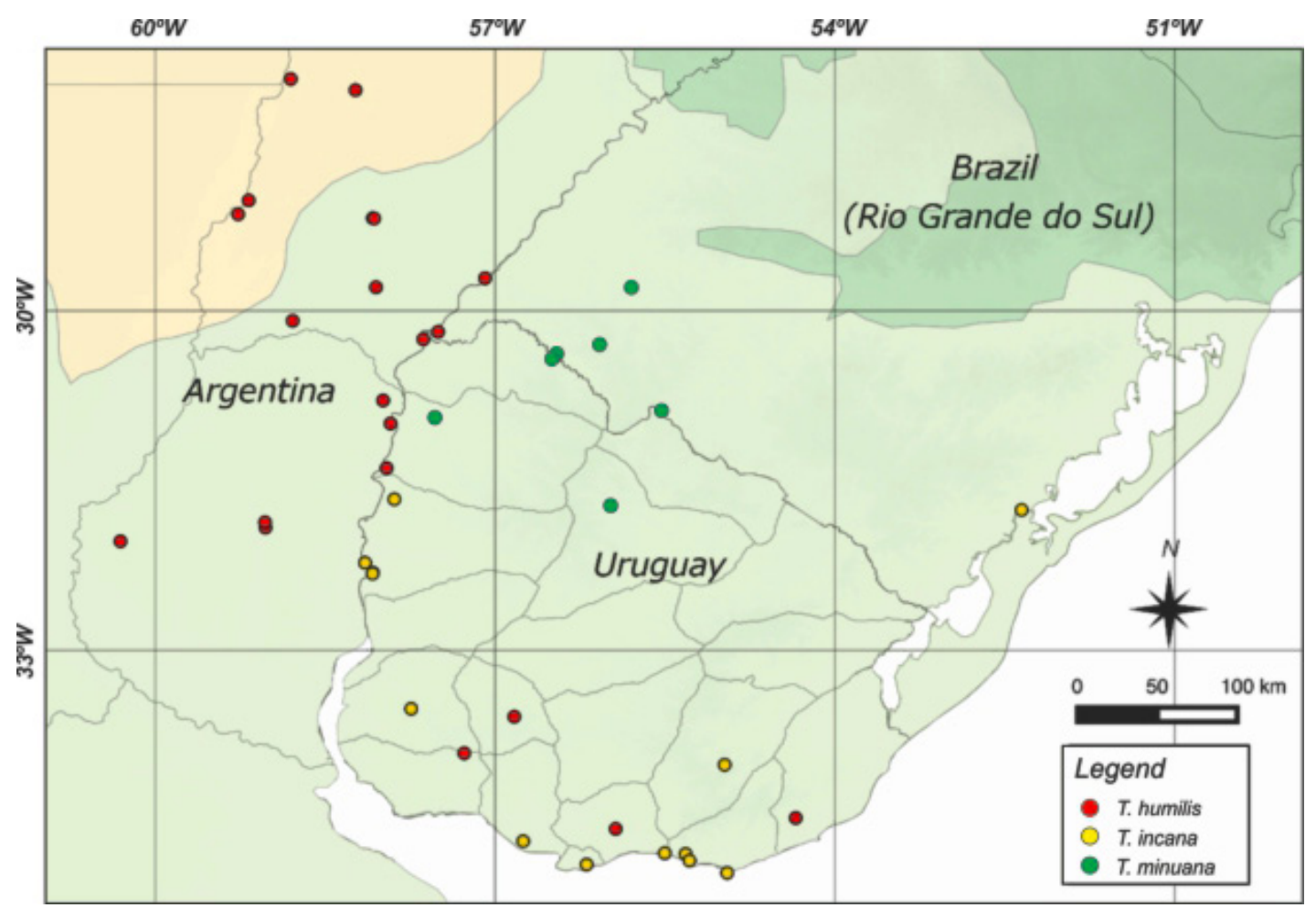

Figure 3 - Distribution map of Trichocline minuana and sympatric species.

consider that the species falls in the endangered (EN) B2ab(iii), Ca(i) category, mainly based on the area of occurrence which was estimated as less than $7,500 \mathrm{~km}^{2}$ (B2), according to GeoCAT analysis. Moreover, it is possible that the population could be facing a decline in number of mature individuals due to low habitat quality, led by the introduction of invasive species and the presence of soy and Eucalyptus L'Hér. monoculture (ab(iii)). Finally, there were less than 250 mature individuals in the localities where the populations were observed, and therefore our estimations are that the species population could have less than 2,500 mature individuals $(\mathrm{Ca}(\mathrm{i}))$.

Flowering and fruiting from December to March.

The species was named after the South American native group Minuanos, which were spread throughout the Pampean region in southern Brazil and Uruguay.

Additional specimens examined: BRAZIL. RIO GRANDE DO SUL: Alegrete, $39 \mathrm{~km} \mathrm{~W}$ from Alegrete, Ruta BR-290, fr., 19.I.1973, A. Krapovickas et al. 22785 (CTES). Quaraí, Cerro do Jarau, 10.XI.1994, C. Mondin (ICN 110212). Quatepe, 19.IV.2011, E. Pasini \& A. Aita 856 (ICN). Santana do Livramento, Morro Vigia, fl., 12.I.1941, B. Rambo (PACA 3853); APA Ibirapuitã, fl., 13.XII.2008, F. Marchett 728 (FUEL, FURB, HUCS, HVAT, ICN). URUGUAY. ARTIGAS: cerca a Catalancito, fl., 30.I.1948, Castellanos (LIL 15456); Ruta 30, 7 km S from Artigas, fl., 10.XII.1995, V. Solis Neffa et al. 243 (CTES). SALTO: Termas del Arapey, fl., 15.I.1967, B. Rosengurtt et al. 10561 (MVFA). TACUAREMBÓ: Valle Edén, fl., XII, J. Chebataroff 5323 (LP); Ruta 5, $\mathrm{km} \mathrm{263,} \mathrm{orilla} \mathrm{de} \mathrm{carretera,} \mathrm{fl.,}$ 20.II.1987, Izaguirre et al. (MVFA 18722); Ruta $5 \mathrm{~km}$ 257, orilla de carretera, fl., 11.XII.1997, E. Marchesi \& I. Grela (MVFA 27074).

\section{Key to distinguish Trichocline minuana from related species}

1. Leaves shiny above, densely tomentose-lanose beneath, scape and involucre densely tomentose-lanose, involucral bracts isomorphic, lanceolate. Trichocline incana

1'. Leaves opaque above, tomentose or glabrescent beneath, scape and involucre tomentose, involucral bracts heteromorphic, spathulate to lanceolate 
2. Developed leaves with margins entire to pinnatisect, glabrescent beneath, small and rounded terminal lobe, lobes rounded, scape up $20 \mathrm{~cm}$, glabrous, involucre glabrous..... Trichocline humilis

2'. Developed leaves with margin strongly pinnatisect, rarely entire, tomentose beneath, large and acute terminal lobe, lobes lanceolate and lacerate, scape never reaching more than $10 \mathrm{~cm}$, involucre tomentose

Trichocline minuana

\section{Acknowledgements}

We would like to thank CAPES (Coordenação de Aperfeiçoamento de Pessoal de Nível Superior) for providing the Ph.D. scholarship of the first author and Carolina Sinischalchi for map design. We are also grateful to Jaqueline Durigon, Daniel Dutra Saraiva and Ângelo Alberto Schneider for providing detailed pictures of the species.

\section{References}

Beentje H (2010) The Kew plant glossary: an illustrated dictionary of plant terms. Royal Botanic Gardens, Kew. 160p.

Cabrera AL \& Willink A (1973) Biogeografia de America Latina. Colección de Monografías Científicas OEA,
Serie Biología, Monografía 13. O.E.A., Washington D.C. 120 p.

IUCN (2016) Guidelines for using the IUCN red list categories and criteria. Version 12. Prepared by the standards and petitions subcommittee. IUCN, Gland and Cambridge. Available at $<$ www.iucnredlist. org $>$. Access on 10 December 2016.

Katinas L, Pruski JF, Sancho G \& Tellería MC (2008) The subfamily Mutisioideae (Asteraceae). The Botanical Review (Lancaster) 74: 469-716.

Thiers B [continuously updated] Index Herbariorum: a global directory of public herbaria and associated staff. New York Botanical Garden's Virtual Herbarium. Available at <http://sweetgum.nybg. org/science/ih/>. Access on 10 December 2016.

Zardini EM (1975) Revisión del género Trichocline (Compositae). Darwiniana 19: 618-733. 